\title{
PENGARUH EKUITAS MEREK TERHADAP PROSES PENGAMBILAN KEPUTUSAN PEMBELIAN MOTOR HONDA BEAT DI DEALER GARUDA MOTOR I KECAMATAN GAMBIRAN KABUPATEN BANYUWANGI
}

\author{
Wardhatul Firdananda H. ${ }^{1}$, Sutrisno Djaja ${ }^{1}$, Sukidin ${ }^{1}$ \\ ${ }^{1}$ Program Studi Pendidikan Ekonomi, Fakultas Keguruan dan Ilmu Pendidikan, Universitas Jember
}

\begin{abstract}
This study was conducted to determine the significant effect of brand equity on consumer decision to buy Honda Beat in Gambiran Banyuwangi. The method of determining the location of research using the method of purposive area is at the dealer Garuda Motor I located on Pb. Sudirman Street 44, Jajag, Gambiran, District Banyuwangi. The number of respondents in this study were many as 75 respondents. Data collection methods used consisted of methods: questionnaires, documents, and interviews. Data analysis used is descriptive analysis and inferential/statistic analysis that is by using simple regression line analysis, regression line variance analysis, F test, regression line effectivity, and Standard Error Of Estimate. The result of the research shows that there is significant influence of brand equity on the process of purchasing decision of Honda Beat at Garuda Motor I dealer in Gambiran of Banyuwangi with Fcount $=308,307>$ Ftable $=3,972$ with significance level $\mathrm{F}=$ $0,000<\mathrm{a}=0,05$. While the contribution of brand equity to the process of making purchasing decisions Honda Beat gi that is equal to $80,9 \%$, while the rest is $19,1 \%$ influenced by other independent variables that are not examined in this study such as location, price level, discounts, and others.
\end{abstract}

Keywords: Brand Equity and Purchase Decision Making Process

\section{PENDAHULUAN}

Perkembangan industri sepeda motor di Indonesia dengan bermacam merek yang digunakan oleh perusahaan menjadikan isu merek ini menjadi sangat strategis dikarenakan dapat mempengaruhi proses pengambilan keputusan pembelian. Menurut data Asosiasi Industri Sepeda Motor Indonesia (AISI) tercatat lebih dari 200 merek sepeda motor yang ada di Indonesia selama kurun waktu 2005 sampai 2016, dengan berbagai segmen pasar dan harga. Beberapa diantaranya yaitu merupakan anggota AISI yakni Honda, Yamaha, Suzuki, Kawasaki, Kanzen, Kymco, dan Piaggio. Masing-masing merek sepeda motor tersebut berlomba melakukan inovasi produk dengan tipe dan pelayanan purna jual, model dan teknologinya masing-masing yang disesuaikan dengan kebutuhan profesi, status, gaya hidup dan penggunanya.

Perusahaan Honda merupakan produsen dan distributor motor yang terkemuka di Indonesia. Perusahaan tersebut juga mempunyai strategi pemasaran untuk mempertahankan konsumen, maka mereka harus melakukan berbagai inovasi dengan tidak lupa menggali kebiasaan, keinginan, dan kebutuhan konsumen di lapangan sebagai upaya inovasi. Motor merek Honda mempunyai keunggulan bahwasannya merupakan motor yang irit dan juga mempunyai keamanan yang tinggi. Citra merek inilah yag dirasa konsumen mampu untuk mengatasi kebutuhan dan juga keinginan mereka. Hal ini sesuai dengan beberapa faktor yang menyebabkan konsumen melakukan proses keputusan pembelian

Seiring dengan perkembangan jaman dan teknologi. produsen sepeda motor terus berinovasi hingga akhirnya lahir jenis sepeda motor bertransmisi otomatis yang kemudian dikenal dengan skutermatik. Salah satu perusahaan yang memproduksi motor skutermatik yaitu perusahaan Honda. Perusahaan Honda merupakan produsen dan distributor motor yang 
terkemuka di Indonesia. Perusahaan tersebut juga mempunyai strategi pemasaran untuk mempertahankan konsumen, maka mereka harus melakukan berbagai inovasi dengan tidak lupa menggali kebiasaan, keinginan, dan kebutuhan konsumen di lapangan sebagai upaya inovasi. Honda mengeluarkan produk dengan segmen skutermatik untuk memuaskan konsumen yaitu Honda Beat, Vario, Scoopy, dan lain-lain.

Beberapa faktor yang menyebabkan konsumen melakukan proses keputusan pembelian produk sepeda motor Honda salah satunya seperti brand image atau citra merek. Masyarakat cenderung tertarik akan produk yang mereknya sudah memiliki citra yang baik serta telah dikenal luas, dan hal ini sangat mungkin dijadikan oleh masyarakat sebagai acuan untuk menilai manakala ada sebuah perusahaan yang memliki merek cukup ternama dan mereknya memiliki reputasi yang baik. Semakin baik merek, maka semakin tinggi keputusan konsumen untuk melakukan pembelian. Honda memiliki citra merek yang berbahan bakar irit dan juga memiliki tingkat keamanan yang tinggi dikelasnya. Hal ini sesuai dengan kebutuhan dan juga keinginan konsumen. Citra merek inilah yang melekat diingatan konsumen sehingga merek dapat mempengaruhi konsumen dalam melakukan proses keputusan pembelian.

Lokasi dalam penelitian ini adalah di dealer Garuda Motor I di Kecamatan Gambiran Kabupaten Banyuwangi. Dealer Garuda Motor I merupakan dealer resmi Honda yang terdapat di Kecamatan Gambiran. Berdasarkan observasi di dealer Garuda Motor I bahwa penjualan motor matic merupakan motor yang paling diminati konsumen saat ini. Menurut pak A selaku manajer dealer Garuda Motor I motor matic yang paling diminati di dealer tersebut yaitu motor Honda Beat series. Hal ini dikarenakan harga motor Honda Beat lebih murah dibandingkan motor skutermatik Honda yang lainnya. Namun, dengan harga yang lebih murah motor Honda Beat sudah memiliki tingkat keamanan dan tehnologi yang baik. Selain itu motor Honda Beat memiliki design yang ramping, pilihan warna yang banyak, dan juga merupakan merek yang cukup populer dikalangan masyarakat.

Berdasarkan latar belakang di atas maka permasalahan dalam penelitian ini yaitu, apakah terdapat pengaruh yang signifikan antara ekuitas merek terhadap proses pengambilan keputusan konsumen membeli motor Honda Beat di delaer Garuda Motor I Kecamatan Gambiran Kabupaten Banyuwangi.

Ada penelitian yang sejenis yang dijadikan acuan bagi peneliti untuk melakukan penelitian ini. Penelitian sejenis yang dilakukan oleh Tosan Widodo (2016) dengan judul "Pengaruh Brand Image, Atribut Produk, dan Harga Terhadap Proses keputusan pembelian Motor Honda Vario di Kulon Progo", dan penelitian yang pernah dilakukan oleh Faisal Afif Lubis (2014) yang berjudul "Analisis Pengaruh Ekuitas Merek Terhadap Keputusan Pembelian Mobil Toyota Avanza (Studi Kasus Toyota Auto 2000 Sisimangaraja)”.

Penetapan merek merupakan persoalan penting dalam strategi produk. Merek yang dikenal luas menentukan harga produk. Perusahaan motor seperti Honda, Yamaha, Suzuki telah berhasil membangun pasar yang luas dengan loyalitas tinggi pada kedua merek tersebut. Bersamaan dengan itu, pengembangan produk bermerek memerlukan investasi besar dalam jangka panjang, terutama untuk periklanan, promosi, dan kemasan.

Kotler dan Keller (dalam Alzamendy, 2011:21) mendefinisikan ekuitas merek sebagai nilai tambah yang diberikan kepada produk dan jasa. Nilai ini bisa dicerminkan dalam bentuk cara seorang konsumen dalam berpikir, merasa, dan bertindak terhadap merek, harga, pangsa 
pasar, dan profitabilitas yang dimiliki perusahaan. Menurut Susanto dan Wijarnako (2004:128) ekuitas merek adalah seperangkat aset dan liabilitas merek yang berkaitan dengan suatu merek, nama dan simbolnya, yang menambah atau mengurangi nilai yang diberikan oleh suatu barang atau jasa kepada perusahaan atau pelanggan. Jadi ekuitas merek merupakan segala kekayaan dalam suatu merek baik nama dan simbol yang secara keseluruhan memiliki konsep multidimensional sehingga meningkatkan profit perusahaan dimasa yang akan datang. Dimana indikator ekuitas merek dalam penelitian ini meliputi kesadaranmerek, asosiasi merek, persepsi kualitas, dan loyalitas merek.

Merek menjadi peranan yang sangat penting dalam ikatan emosional yang tercipta antara konsumen dan perusahaan penghasil produk melalui merek. Merek yang dibangun dengan penciptaan struktur mental yang berhubungan dengan perusahaan pada ingatan konsumen akan membantu konsumen dalam membantu melakukan proses keputusan pembelian. Hal tersebut sesuai dengan pendapat Swastha dan Handoko (dalam Megawati, 2013:27) Keputusan untuk membeli yang diambil oleh pembeli sebenarnya merupakan kumpulan dari sejumlah keputusan yang terstruktur, salah satunya adalah keputusan tentang merek.

Menurut Suharno (2010:96) keputusan pembelian adalah tahap di mana pembeli telah menentukan pilihannya dan melakukan pembelian produk, serta mengkonsumsinya. Seorang konsumen harus dapat mengambil keputusan tentang merek mana yang harus dibeli karena setiap merek memiliki perbedaan-perbedaan tersendiri. Yulisetiarini (2014:34) menyatakan beberapa keuntungan yang diberikan oleh merek antara lain: merek itu adalah sekaligus sales promotion, memberi dorongan untuk melakukan pembelian, melindungi peniruan atau persaingan dari penggantinya, dan memudahkan jika di kemudian akan dikenalkan produk yang baru. Dalam rangka memberikan manfaat fungsional, pernyataan nilai sebuah merek dapat mencakup manfaat emosional dan manfaat ekspresi diri. Menurut Durianto dkk (2004:61) seluruh elemen ekuitas merek dapat mempengaruhi keputusan pembelian konsumen karena ekuitas merek yang kuat akan mengurangi keinginan konsumen untuk berpindah ke merek lain.

Berdasarkan penjelasan tersebut, maka hipotesis dari penelitian ini adalah: ada pengaruh yang signifikan ekuitas merek terhadap proses pengambilan keputusan pembelian motor merek Honda Beat di Kecamatan Gambiran Kabupaten Banyuwangi.

\section{METODE PENELITIAN}

Penelitian ini merupakan penelitian deskriptif kuantitatif. Metode penentuan lokasi penelitian menggunakan metode purposive area yaitu di dealer Garuda Motor I yang terletak di Jalan Pb. Sudirman 44, Jajag, Kecamatan Gambiran Kabupaten Banyuwangi. Jumlah responden dalam penelitian iniyaitu sebanyak 75responden. Metode pengumpulan data yang digunakan terdiri dari metode: angket, dokumen, dan wawancara.Analisis data yang digunakan adalah analisis deskriptif dan analisis inferensial/statistik yaitu dengan menggunakan analisis garis regresi sederhana yaitu dengan menggunakan rumus sebagai beikut:

$$
\hat{\mathrm{Y}}=\mathrm{a}+\mathrm{bX}+e i
$$

Untuk analisis varian garis regresi yaitu untuk mengetahui kuat tidaknya atau tingkat keeratan variabelekuitas merek terhadap pengambilan keputusan konsumen membeli motor 
Honda Beat di Kecamatan Gambiran Kabupaten Banyuwangiyaitu dengan rumus sebagai berikut:

$$
\mathrm{Ry}=\sqrt{\frac{a \sum X Y}{\sum Y^{2}}}
$$

Sedangkan uji $\mathrm{F}$ yaitu untuk mengetahui pengaruh yang signifikan variabel ekuitas merek terhadap pengambilan keputusan konsumen membeli motor Honda Beat di Kecamatan Gambiran Kabupaten Banyuwangi dengan rumus sebagai berikut:

$$
\mathrm{F}_{\text {hit }}=\frac{R^{2} / K}{\left(1-R^{2}\right) /(n-k-1)}
$$

Untuk uji efektivitas garis regresi yaituuntuk mengetahui berapa besar (\%) pengaruhvariabel ekuitas merek terhadap pengambilan keputusan konsumen membeli motor Honda Beat di Kecamatan Gambiran Kabupaten Banyuwangi dengan rumus sebagai berikut:

$$
\mathrm{R}^{2}(1) \times 100 \%=\ldots . . \%
$$

Terakhir yaitu untuk Standart Error of Estimate digunakan untuk mengukur variasi nilai Y aktual dari garis regresinya.

\section{HASIL DAN PEMBAHASAN}

\section{Hasil Penelitian}

Hasil penelitian ini yaitu meliputi data pendukung dan data utama yang meliputi uji instrumen penelitian, analisis deskriptif dan analisis inferensial. Analisis deskriptif ini berguna untuk mendukung hasil analisis data. Berdasarkan penelitian yang telah dilakukan dapat diketahui bahwa ekuitas merek meliputi kesadaran merek, asosiasi merek, persepsi kualitas, dan loyalitas merek berpengaruh terhadap proses pengambilan keputusan konsumen membeli motor Honda Beat di dealer Garuda Motor I Kecamatan Gambiran Kabupaten Banyuwangi. Dimana adanya ekuitas merek, maka akan memudahkan dan mempercepat proses pengambilan keputusan konsumen membeli motor Honda Beat di dealer Garuda Motor I Kecamatan Gambiran Kabupaten Banyuwangi. Berdasarkan presentase angket menyatakan bahwa indikator kesadaran merek dan asosiasi merek mempunyai presentase yang paling tinggi dibandingkan indikator persepsi kualitas dan loyalitas merek. Hal ini dikarenakan motor Honda Beat memiliki merek yang mudah diingat oleh konsumen, merek motor Honda Beat sering konsumen lihat atau dengar di media cetak ataupun media elektronik sehingga konsumen sudah mengetahui kesesuaian motor Honda Beat dengan gaya hidup dan kebutuhan konsumen. Selain itu, motor merek Honda Beat juga sudah memiliki citra merek dibenak konsumen.

Analisis inferensial digunakan untuk menjawab rumusan masalah yaitu untuk mengetahui pengaruh yang signifikanekuitas merek terhadap pengambilan keputusan konsumen membeli motor Honda Beat di Kecamatan Gambiran Kabupaten Banyuwangi. Berdasarkan analisis data yang dilakukandiperoleh hasil dalam tabel berikut ini:

Tabel Ringkasan Uji F, Multiple R, dan R Square

\begin{tabular}{ccccccc}
\hline Variabel & $\mathrm{F}_{\text {Hitung }}$ & $\mathrm{F}_{\text {Tabel }}$ & Sig. F & $a$ & $\mathrm{R}$ & $\mathrm{R}_{\text {Square }}$ \\
\hline X terhadap Y & 308,307 & 3,972 & 0,000 & 0,05 & $0,899^{\mathrm{a}}$ & 0,809 \\
\hline
\end{tabular}

Sumber: Data diolah 2017 
Tabel di atas menunjukkan bahwa $\mathrm{F}_{\text {hitung }}=308,307>\mathrm{F}_{\text {tabel }}=3,972$ dengan tingkat signifikansi $\mathrm{F}=0,000<a=0,05$. Hal ini menunjukkan bahwa variabel ekuitas merek memiliki pengaruh yang signifikan terhadap pengambilan keputusan konsumen membeli motor Honda Beat di Kecamatan Gambiran Kabupaten Banyuwangi. Untuk koefisien determinasi

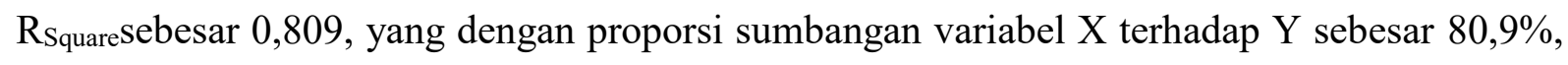
sedangkan sisanya yaitu 19,1\% dipengaruhi variabel bebas lainnya yang tidak diteliti dalam penelitian ini seperti lokasi, tingkat harga, potongan harga, dan lain-lain. Hubungan ekuitas merek terhadap pengambilan keputusan konsumen membeli motor Honda Beat di Kecamatan Gambiran Kabupaten Banyuwangi dapat diketahui dari multiple $\mathrm{R}$ sebesar 0,899 dengan kategori hubungan yang sangat kuat.

\section{Pembahasan}

Penelitian ini dilakukan untuk mengetahui pengaruh yang signifikan variabel ekuitas merek terhadap proses pengambilan keputusan pembelian motor Honda Beat di dealer Garuda Motor I Kecamatan Gambiran Kabupaten Banyuwangi. Hipotesis yang menyatakan bahwa ada pengaruh yang signifikan variabel ekuitas merek $(\mathrm{X})$ terhadap proses keputusan pembelian $(\mathrm{Y})$ motor Honda Beat di Dealer Garuda Motor I Kecamatan Gambiran Kabupaten Banyuwangi diterima atau mempunyai pengaruh positif yang signifikan terhadap proses keputusan pembelian. Hal ini artinya hipotesis tersebut terjawab secara simultan ekuitas merek berpengaruh terhadap proses pengambilan keputusan pembelian sebesar 80,9\%.

Dimana ekuitas merek meliputi kesadaran merek, asosiasi merek, persepsi kualitas, dan loyalitas merek. Menurut Surachman (2008:7) kesadaran merek merupakan kesanggupan seorang calon pembeli untuk mengenali atau mengingat kembali bahwa suatu merek merupakan bagian dari kategori produk tertentu yaitu produk Honda Beat. Berdasarkan penelitian yang telah dilakukan, dapat diketahui bahwa kesadaran mereka yang ditunjukkan oleh para konsumen yang membeli motor Honda Beat di dealer Garuda Motor I Kecamatan Gambiran Kabupaten Banyuwangi yang menjadi responden dalam penelitian ini yaitu konsumen menganggap merek Honda Beat merupakan merek motor yang pertama muncul dalam benak responden dan familiar (tidak asing) dibenak responden. Hal ini dikarenakan motor Honda Beat memiliki design yang memiliki ciri-ciri khusus sehingga mudah dikenali konsumen dan juga merek Honda Beat merupakan merek motor yang sering responden lihat/dengar di media cetak maupun elektronik.

Asosiasi merek adalah segala kesan yang muncul dan terkait dengan ingatan kosnumen mengenai suatu merek yang mencerminkan pencitraan suatu merek terhadap suatu kesan tertendu dalam kaitannya dengan kebiasaan, gaya hidup, manfaat, atribut produk, geografis, harga pesaing, dan lain-lain (Winatapradja, 2013:959). Adapun bentuk dari asosiasi merek yang ditunjukkan oleh responden yaitu responden menganggap bahwa motor Honda Beat memiliki desaign yang modern, memberikan banyak pilihan warna, motor Honda Beat memiliki fitur yang lengkap, harga Motor Honda Beat sesuai dengan kemampuan atau daya beli masyarakat, motor Honda Beat memberikan dan menambah rasa percaya diri, dan responden menganggap bahwa Honda Beat merupakan motor yang dikenal dikalangan masyarakat sehingga mudah menjual kembali dengan nilai jual yang stabil. 
Menurut Simamora (dalam Megawati, 2013:19) persepsi kualitas adalah persepsi pelanggan terhadap kualitas atau keunggulan suatu produk yaitu motor Honda Beat ditinjau dari fungsinya secara relatif dengan produk-produk lain. Berdasarkan penelitian yang dilakukan dapat diketahui bahwa beberapa bentuk persepsi kualitas yang ditunjukkan oleh responden meliputi: responden beranggapan bahwamotor Honda Beat merupakan motor matic yang irit,daya tahan mesin tangguh untuk jarak menengah hingga jauh, sepeda motor Honda Beat memiliki daya tahan mesin yang tangguh sehingga dapat dipakai disegala macam cuaca, motor Honda Beat lincah dikendarai di jalanan yang padat maupun jalanan yang lancar, motor Honda Beat memilik tingkat keamanan yang tinggi, adanya kesamaan antara iklan dengan kualitas motor Honda Beat yang ditawarkan, dan motor Honda Beat mempunyai kualitas yang dapat dipercaya.

Selanjutnya, loyalitas merek adalah preferensi konsumen secara konsisten untuk melakukan pembelian pada merek yang sama pada produk yang spesifik atau kategori pelayanan tertentu. Loyalitas merek adalah sebuah komitmen yang kuat dalam berlangganan atau membeli suatu merek secara konsisten di masa yang akan datang (Schiffman dan Kanuk, dalam Rizan, 2012:6). Adapun bentuk dari loyalitas merek yang ditunjukkan oleh responden yaitu responden tetap memilih dan membeli motor Honda Beat meskipun ada perubahan harga, responden menemukan kepuasaan dalam menggunakan motor Honda Beat, responden benarbenar menyukai motor Honda Beat, responden akan kembali setia membeli motor Honda Beat, dan responden akan merekomendasikan kepada orang lain untuk membeli motor Honda Beat.

Variabel ekuitas merek dengan indikator kesadaran merek, asosiasi merek, persepsi kualitas, dan loyalitas merek signifikan memberikan pengaruh signifikan terhadap variabel proses keputusan pembelian (Y). Berdasarkan presentase angket menyatakan bahwa indikator kesadaran merek dan asosiasi merek mempunyai presentase yang paling tinggi dibandingkan indikator persepsi kualitas dan loyalitas merek. Hal ini dikarenakan motor Honda Beat memiliki merek yang mudah diingat oleh konsumen, merek motor Honda Beat sering konsumen lihat atau dengar di media cetak ataupun media elektronik sehingga konsumen sudah mengetahui kesesuaian motor Honda Beat dengan gaya hidup dan kebutuhan konsumen. Selain itu, motor merek Honda Beat juga sudah memiliki citra merek dibenak konsumen. Berikut merupakan penjelasan dari salahs atu responden dalam penelitian ini.

"....................saya akan merekomendasikan kepada orang lain serta akan melakukan pembelian motor Honda Beat tersebut mbak, karena saya merasa puas dengan kualitas merek yang saya rasakan mbak, karena selain harganya yang terjangkau, kualitasnya yang terpercaya, juga harga jualnya yang stabil mbak. Oleh karena itulah saya akan merekomendasikan kepada teman maupun saudara mbak." (AH, 37 $\left.7^{\mathrm{Th}}\right)$.

Berdasarkan penelitian yang telah dilakukan dapat diketahui bahwa ekuitas merek meliputi kesadaran merek, asosiasi merek, persepsi kualitas, dan loyalitas merek berpengaruh terhadap proses pengambilan keputusan konsumen membeli motor Honda Beat di dealer Garuda Motor I Kecamatan Gambiran Kabupaten Banyuwangi. Dimana adanya ekuitas merek, maka akan memudahkan dan mempercepat proses pengambilan keputusan konsumen membeli motor Honda Beat di dealer Garuda Motor I Kecamatan Gambiran Kabupaten Banyuwangi. 
Untuk proses pengambilan keputusan konsumen membeli motor Honda Beat di dealer Garuda Motor I Kecamatan Gambiran Kabupaten Banyuwangi meliputi pengenalan kebutuhan, pencarian informasi, evaluasi alternatif, dan keputusan pembelian. Berikut merupakan penjelasan tambahan dari responden dalam penelitian ini..

"adanya kualitas yang bagus membuat saya membeli motor Honda Beat karena motor Honda Beat memiliki kualitas yang bagus, lumayan irit, memiliki warna yang menarik, harga yang terjangkau, serta cocok digunakan oleh perempuan maupun laki-laki mbak, oleh karena itulah saya memutuskan untuk membeli motor Honda Beat" (AH, $37^{\text {Th }}$ ).

Berdasarkan pendapat tersebut dapat diketahui bahwa dengan adanya merek yang berkualitas maka berpengaruh pada proses pengambilan keputusan pembelian oleh konsumen pada motor Honda Beat. Merek menjadi peranan yang sangat penting dalam ikatan emosional yang tercipta antara konsumen dan perusahaan penghasil produk melalui merek. Merek yang dibangun dengan penciptaan struktur mental yang berhubungan dengan perusahaan pada ingatan konsumen akan membantu konsumen dalam membantu melakukan proses keputusan pembelian. Hal tersebut sesuai dengan pendapat Swastha dan Handoko (dalam Megawati, 2013:27) Keputusan untuk membeli yang diambil oleh pembeli sebenarnya merupakan kumpulan dari sejumlah keputusan yang terstruktur, salah satunya adalah keputusan tentang merek. Seorang konsumen harus dapat mengambil keputusan tentang merek mana yang harus dibeli karena setiap merek memiliki perbedaan-perbedaan tersendiri.

Jadi, suatu produk dengan merek yang kuat seperti pada Motor Honda Beat dapat menciptakan nilai bagi pelanggan yang dapat mempengaruhi pelanggan dalam melakukan proses keputusan pembelian terhadap produk tersebut, sehingga kepuasan pelanggan akan meningkat bilamana pelanggan merasa produk yang dibeli mepunyai kualitas dan asosiasi merek yang postif. Selain itu, dapat meningkatkan loyalitas terhadap merek tersebut karena dipersepsi berkualitas. Dimana ekuitas merek yang dimiliki oleh motor Honda Beat tersebut dapat mempengaruhi proses pengambilan keputusan pembelian pada konsumen. Hal tersebut sesuai dengan pendapat Durianto dkk (2004:61) yang menjelaskan bahwa seluruh elemen ekuitas merek dapat mempengaruhi keputusan pembelian konsumen karena ekuitas merek yang kuat akan mengurangi keinginan konsumen untuk berpindah ke merek lain.

Berdasarkan pemaparan di atas dapat disimpulkan bahwa variabel ekuitas merek merupakan salah satu faktor yang mempengaruhi proses pengambilan keputusan pembelian motor Honda Beat di dealer Garuda Motor I Kecamatan Gambiran Kabupaten Banyuwangi. Berdasarkan hasil penelitian dan pembahasan dalam penelitian ini membuktikan bahwa hipotesis dalam penelitian ini diterima yaitu ada pengaruh yang signifikan ekuitas merek terhadap proses pengambilan keputusan pembelian motor Honda Beat di dealer Garuda Motor I Kecamatan Gambiran Kabupaten Banyuwangi. 


\section{KESIMPULAN DAN SARAN}

\section{Kesimpulan}

Berdasarkan analisis data dan hasil pembahasan penelitian yang telah diuraikan pada bab sebelumnya, maka dapat disimpulkan bahwa ada pengaruh yang signifikan ekuitas merek terhadap proses pengambilan keputusan pembelian motor Honda Beat di dealer Garuda Motor I Kecamatan Gambiran Kabupaten Banyuwangi. Hasil penelitian menyatakan indikator dalam variabel ekuitas merek yang paling dominan adalah indikator kesadaran merek dan asosiasi merek, dibandingkan indikator persepsi kualitas dan loyalitas merek. Oleh karena itu, dengan adanya ekuitas merek motor Honda Beat yang tinggi menyebabkan keputusan pembelian motor Honda Beat oleh konsumen juga semakin tinggi.

\section{Saran}

Berdasarkan kesimpulan di atas dari penelitian ini, maka peneliti ingin memberikan saran yaitubagi pihakdealer Garuda Motor I, sebaiknya meningkatkan variasi produk yang dijual. Bagi masyarakat, hendaknya lebih meningkatkan pengetahuan terhadap informasi kualitas pada kendaraan bermotor jika berkeinginan untuk melakukan pembelian kendaraan bermotor. Dan bagi peneliti lain,diharapkan bagi peneliti lain yang akan melakukan penelitian serupa dengan penelitian ini untuk mengambil variabel lain yang tidak turut diteliti dalam penelitian ini, supaya dapat menciptakan penelitian-penelitian yang lebih baik dan nantinya sebagai tambahan referensi penelitian yang sejenis.

\section{DAFTAR BACAAN}

Durianto, Damadi, dkk. 2004. Strategi Menaklukan Pasar. Jakarta: Gramedia.

Suharno. 2010. Marketing in Practice. Yogyakarta: Graha Ilmu.

Surachman, S.A. 2008. Dasar-Dasar Manajemen Merek. Malang: Bayumedia Publishing

Wijanarko, H. 2013. Power Branding: Membangun Merek Unggul dan Organisasi Pendukungnya. Jakarta : PT Mizan Publika Jakarta.

Yulisetiarini, Diah. 2014. Intisari Marketing. Jember: Cahaya Ilmu Jember.

Afif, F.L. 2014. Analisis Pengaruh Ekuitas Merek Terhadap Keputusan Pembelian Mobil Toyota New Avanza (Studi Kasus Toyota Auto 2000 Sisingamangaraja). Skripsi. Fakultas Ilmu sosial dan Ilmu Politik-Departemen Ilmu Administrasi Bisnis- Universita Sumatera Utara.

Alzamendy, M. 2011. Analisis Pengaruh Ekuitas MerekTerhadap Keputusan Pembelian MobilSuzuki Swift (Studi Kasus pada KonsumenSuzuki Swift di Semarang). Skripsi. Fakultas Ekonomi-Universitas Diponegoro.

Megawati, Anita. 2013. Pengaruh Merek Terhadap Keputusan PembelianSoft Drink. Skripsi. Jember: Universitas Negeri Jember

Rizan, M., B. Saidani, dan Y. Sari. 2012. Pengaruh Brand Image dan Brand Trust Terhadap Brand Loyalty Teh Botol Sosro. Jurnal Riset Manajemen Sains Indoneisa, Vol. 3, No. 1, pp. 1-17.

Widodo, T. 2016. Pengaruh Brand Image, Atribut Produk Dan HargaTerhadap Keputusan Pembelian Sepeda Motor Honda VarioDi Kulon Progo. Skripsi. Fakultas EkonomiUniversitas Negeri Yogyakarta.

Winatapradja, Nabila. 2013. Ekuitas Merek Pengaruhnya Terhadap Keputusan Pembelian Produk Donat J.CO Donuts \& Coffee di Manado Town Square. Manado: Fakultas Ekonomi Universitas Sam Ratulangi. 